\title{
PERAN LIFE CYCLE STAGE DALAM MEMODERASI HUBUNGAN \\ ANTARA INTELLECTUAL CAPITAL DISCLOSURE DAN NILAI PERUSAHAAN
}

\author{
ARIF PUJIANTO, WIWIK UTAMI, ISTIANINGSIH SASTRODIHARJO \\ Universitas Mercu Buana \\ wiwikutami@gmail.com
}

\begin{abstract}
The purpose of this study was to identify interactive effect of the life cycle stage on the relationship of intellectual capital disclosure and corporate value. Components of intellectual capital disclosure is human capital disclosure, structure capital disclosure and customer capital disclosure. Life cycle stage was interest to be reviewed as there are differences finding on previous research.The population were manufacturing companies listed on the Indonesia Stock Exchange during the period 2009 - 20II.Based on purposive sampling there were 70 companies was selected. The multiple regression method was used to analyze the interactive effect. The results of this study demonstrate that Life cycle stages not moderates the relationship of intellectual capital disclosure and corporate value. This finding has an important role in the management accounting literature Keywords: Life Cycle Stage, Intellectual Capital Disclosure, Corporate Value, Size and Leverage
\end{abstract}

\section{Abstrak}

Tujuan dari penelitian ini adalah untuk mengidentifikasi efek interaktif dari tahap siklus hidup pada hubungan pengungkapan modal intelektual dan nilai perusahaan. Komponen pengungkapan modal intelektual adalah pengungkapan modal manusia, modal pengungkapan struktur dan pengungkapan modal pelanggan. Siklus hidup adalah menarik untuk dikaji karena ada perbedaan hasil penelitian sebelumnya. Populasi dalam penelitian ini adalah perusahaan manufaktur yang terdaftar di Bursa Efek Indonesia selama periode 2009 20II.Based purposive sampling ada 70 perusahaan terpilih. Metode regresi berganda digunakan untuk menganalisis pengaruh interaktif. Hasil penelitian ini menunjukkan bahwa siklus hidup idak memoderasi hubungan pengungkapan modal intelektual dan nilai perusahaan. Temuan ini memiliki peran penting dalam literatur akuntansi manajemen Kata Kunci: Siklus hidup, Intelektual Capital dan Nilai Perusahaan

DIterima: 18 Januari 2016; Direvisi: 22 Februari 2016; Disetujui: 17 Maret 2016

http://journal.uinjkt.ac.id/index.php/akuntabilitas 


\section{PENDAHULUAN}

Implementasi intellectual capital merupakan sesuatu yang baru bukan hanya di Indonesia tetapi juga di lingkungan bisnis global. Pada umumnya kalangan bisnis masih belum menemukan jawaban yang tepat mengenai nilai lebih apa yang dimiliki oleh perusahaan. Nilai lebih ini sendiri dapat berasal dari kemampuan berproduksi suatu perusahaan sampai pada loyalitas pelanggan terhadap perusahaan. Nilai lebih ini dihasilkan oleh modal intelektual yang dapat diperoleh dari budaya pengembangan perusahaan maupun kemampuan perusahaan dalam memotivasi karyawannya sehingga produktivitas perusahaan dapat dipertahankan atau bahkan dapat meningkat (Sawarjuwono dan Prihatin Kadir, 2003).

Penelitian yang dilakukan Bontis et al. (2000) di malaysia pada pengujian intellectual capital yang terdiri dari human capital, structural capital dan customer capital terhadap kinerja perusahaan menunjukkan bahwa human capital dan customer capital menjadi faktor yang signifikan dalam melaksanakan usaha perusahaan dan structural capital memiliki pengaruh positif pada kinerja perusahaan. Reed (2000) di US Amerika melakukan pengujian empiris pengaruh intellectual capital dan kinerja di industri perbankan. Hasil penelitian tersebut menunjukkan bahwa intellectual capital menjadi faktor yang sangat kuat untuk memprediksi kinerja perbankan. Belkaoui (2003) melakukan penelitian untuk menguji intellectual capital pada kinerja perusahaan multinasional di US Amerika dan diperoleh hasil bahwa intellectual capital memiliki pengaruh positif pada kinerja perusahaan.

Hasil penelitian yang menemukan hubungan positif antara intellectual capital dan kinerja antara lain adalah Firer dan Williams (2003), Chen et al. (2005) dan Tailes et al., (2006), Cohen dan Kaimenakis (2007), Ten et al. (2007). Penelitian di Indonesia yang dilakukan oleh Wijanto dan Istianingsih (2008) dengan menggunakan metode latent growt curve modeling untuk menguji hubungan jangka panjang pertumbuhan intellectual capital dan kinerja perusahaan, juga berhasil membuktikan adanya hubungan positif antara kepemilikan intellectual capital dan kinerja perusahaan. Sementara itu Bukh et al (200I) berpendapat bahwa intellectual capital lebih berpengaruh terhadap struktur organisasi dan strategi dibandingkan dengan modal yang berasal dari pasar modal. 
Nilai perusahaan pada dasarnya dapat diukur melalui beberapa aspek, salah satunya adalah harga pasar saham perusahaan karena mencerminkan penilaian investor keseluruhan dari setiap ekuitas yang dimiliki. Menurut Van Home (1998) menjelaskan bahwa harga saham menunjukan nilai sentral diseluruh pelaku pasar, harga pasar bertindak sebagai barometer kinerja manajemen. Bagi perusahaan go public maka nilai pasar perusahaan ditentukan mekanisme permintaan dan penawaran di bursa, yang tercermin dalam harga saham (listing price). Sedangkan bagi yang bukan perusahaan publik, nilai pasar ditetapkan oleh lembaga independen seperti perusahaan jasa penilai (appraisal company). Harga pasar merupakan cerminan berbagai keputusan dan kebijakan manajemen dengan demikian nilai perusahaan merupakan akibat dari tindakan manajemen, Suharli (2006).

Wijaya (2010). Semakin tinggi harga saham, semakin tinggi nilai perusahaan. Nilai perusahaan yang tinggi adalah keinginan para pemilik perusahaan, karena dengan nilai yang tinggi menunjukkan kemakmuran pemegang saham juga tinggi. Untuk mencapai nilai perusahaan, umumnya para pemodal menyerahkan pengelolaannya kepada para professional, para profesional diposisikan sebagai manajer ataupun komisaris, Soliha dan Taswan (2002).

Penelitian dan praktisi di bidang akuntansi dan keuangan memiliki pandangan yang beragam tentang penilaian suatu perusahaan. Ada pihak yang beranggapan bahwa nilai suatu perusahaan tercermin dalam kinerja laporan keuangan perusahaan. Myers dalam Gaver dan Gaver (1995) mengungkapkan bahwa konsep nilai perusahaan adalah suatu kombinasi aktiva yang dimiliki (asset in place) dan pilihan investasi dimasa mendatang.

Penilaian perusahaan juga dapat dikaitkan dengan siklus kehidupannya, artinya dengan memperhatikan siklus hidup perusahaan dapat dinilai apakah pencapaian perusahaan sesuai dengan siklus hidup yang dialami. Gup dan Agrrawal (1996) menyatakan bahwa setiap perusahaan pasti mengalami siklus kehidupan, dimana siklus tersebut identik dengan siklus kehidupan perusahaan, tahapan dari siklus kehidupan perusahaan secara berturut adalah tahapan pendirian (establishment or start-up), tahap ekspansi (expansion), tahap kedewasaan (maturity) dan tahap penurunan (declining) 
Penelitian life cycle stage masih terdapat perbedaan pendapat, hal tersebut dijelaskan dalam penelitian dilakukan oleh Gul (1999) dan Lestari (2004) menunjukan pada tahap awal (start-up) perusahaan memiliki hubungan negatif hal ini mengindisikan bahwa perusahaan lebih cenderung menginvestasikan kembali laba dan meningkatkan pertumbuhan perusahaan sehingga dividen yang dibayar lebih rendah dengan yang diinvestasikan kembali oleh perusahaan. Pada tahap ekspansi (expansion) dan kedewasaan (Mature) penelitian Pagalung (2002) menunjukan memiliki hubungan positif terhadap kesempatan berinvestasi, tetapi hal tersebut berbanding terbalik dengan penelitian AINajjar dan Belkoui (200I) bahwa pada tahap ekspansi (expansion) dan kedewasaan (Mature) berpengaruh negatif terhadap kesempatan berinvestasi.

Penelitian ini ingin mengetahui dan menginvestigasi intellectual capital dan nilai perusahaan, serta menguji peran life cycle stage dalam memoderasi hubungan tersebut. Kontribusi yang dihasilkan adalah memberikan tambahan literatur terhadap penelitian mengenai intellectual capital yang masih terbatas dengan memasukkan variabel life cycle stage sebagai variabel moderasi.

Berdasarkan penelitian terdahulu dan fakta-fakta baru yang ada maka penelitian ini bertujuan untuk memberikan bukti empiris berkaitan dengan pertanyaan : (I) apakah intellectual capital disclosure mempunyai pengaruh terhadap nilai perusahaan dan (2) apakah life cycle stage memoderasi hubungan antara intellectual capital disclosure dan nilai perusahaan.

\section{KERANGKA TEORI DAN PENGEMBANGAN HIPOTESIS}

\section{Agecy Theory dan Political Cost Theory}

Dalam hal ini Agency theory menempatkan pengungkapan sebagai mekanisme yang dapat mengurangi biaya yang dihasilkan dari konflik antara manajer dengan pemegang saham (compensation contracts) dan konflik antara perusahaan dan kreditornya (debt contracts). Oleh karena itu, pengungkapan merupakan mekanisme untuk mengontrol kinerja manajer. Sebagai konsekuensinya, manajer didorong untuk mengungkap voluntary information seperti intellectual capital disclosure. Menurut political cost theory, perusahaan yang merupakan politically visible dan subjek high political cost (tergantung pada ukuran perusahaan), akan cenderung mengungkapkan 
intellectual capital lebih banyak. Political cost hypothesis menunjukkan bahwa perusahaan besar lebih cenderung untuk menggunakan pilihan akuntansi yang mengurangi pelaporan laba, daripada perusahaan kecil (Watts dan Zimmerman, 1990).

\section{Resource Based View Theory}

Sumber daya yang dimiliki perusahaan dapat menciptakan nilai tambah bagi perusahaan, pada Resource Based View Theory dinyatakan bahwa sumber daya perusahaan yang unik dan tidak mudah ditiru oleh pesaing akan membuat perusahaan lebih mampu untuk bersaing dan mempertahankan keunggulan kompetitif melalui implementasi yang bersifat strategik (Barney, Cornner, 199I dan Schulze, 1992) dalam (Sonier, 2008) Dalam Resource-Based theory menjelaskan terdapat tiga jenis sumber daya yaitu sumber daya fisik berupa pabrik, teknologi, peralatan, lokasi geografis, sumber daya manusia berupa pengalaman, pengetahuan pegawai, dan sumber daya organisasional berupa struktur dan sistem perencanaan, pengawasan, pengendalian, serta hubungan sosial antar organisasi dengan lingkungan eksternal (Jackson \& Schuler, 1995)

\section{Signalling Theory}

Adanya karakteristik khusus dalam perusahaan akan memberikan adanya perbedaan kualitas informasi antar perusahaan, karena adanya perbedaan informasi (asymmetric information) yang dimiliki antara perusahaan, maka manajer akan berusaha memberikan sinyal (signal) mengenai informasi yang dimilikinya kepada investor dan memastikan bahwa sinyal tersebut merupakan informasi yang dapat dipercaya. Dalam hal ini signaling theory dapat dinyatakan secara langsung melalui pengungkapan dalam laporan keuangan tahunan perusahaan, atas dasar tersebut informasi tentang intellectual capital dapat diungkapkan secara langsung kepada investor melalui pengungkapan sukarela dalam laporan keuangan tahunan perusahaan. Spence (1973) menjelaskan bahwa Signaling theory perusahaan dengan kinerja yang tinggi menggunakan informasi keuangan untuk mengirim sinyal kepada pasar. Oleh karena itu, manajer lebih termotivasi untuk mengungkapkan intellectual capital sebagai private information secara sukarela. Hal ini disebabkan oleh ekspektasi 
manajer bahwa menyediakan sinyal yang bagus mengenai kinerja perusahaan kepada pasar akan mengurangi asymmetric information (Oliveira et al., 2008)

\section{Intellectual capital}

Istilah Intellectual capital seringkali disebut intangible assets sebagai sinonim (Meritum, 2002; Lev, 200I; dan LEV dan Zambon, 2003), menurut FASB (200I) menyatakan intangible assets bukan hanya suatu hasil dari research and development tetapi juga sumber daya manusia, hubungan dengan pelanggan dan inovasi. Para peneliti non akuntansi mendefinisikan Intellectual capital sebagai perbedaan antara nilai buku dengan nilai pasar dari suatu entitas (Edvinsson dan Malone, 1997; Stewart, 1997; Sveiby, 1997; Mouritsen et al., 200I) sedangkan para peneliti akuntansi perbedaan antara nilai buku dengan nilai pasar suatu entitas merupakan goodwill yang merupakan intangible assets (Ohlson, 1995; Feltham dan Ohlson, 1996; Beaver, 1998; Holthausen dan Watts, 200I). Intellectual capital menurut beberapa peneliti terdiri dari tiga bagian utama yang terdiri dari human capital, structural capital, dan customer capital.

Human capital merupakan bagian dari intellectual capital yang merupakan sumber daya strategis berupa pengetahuan, keterampilan dan kompetensi yang sangat bernilai bagi perusahaan, human capital mencerminkan kemampuan kolektif perusahaan untuk menghasilkan solusi terbaik, berdasarkan pengetahuan yang dimiliki oleh orang-orang yang berada di perusahaan tersebut. Human capital merupakan kombinasi dari pengetahuan, keahlian (skill), attitudes, kemampuan melakukan inovasi dari karyawan dalam penyelesaian tugas perusahaan (GarciaMeca, 2006). Komponen human capital meliputi pengalaman, kepemimpinan, enterpreunerial and managerial skills, teamwork capacity, fleksibilitas, tolerance for ambiguity, motivasi, learning capacity, loyalitas formal training, dan pendidikan karyawan (Brooking, 1996; Meritum, 2002). Dalam intellectual capital, Human Capital merupakan Investasi dalam pelatihan meningkatan sumber daya manusia yang merupakan investasi yang amat penting, karena pengalaman, skill dan pengetahuan yang dimiliki sumber daya manusia mempunyai nilai ekonomi yang tinggi bagi perusahaan untuk menciptakan produktivitas dan kemampuan beradaptasi (Kannan dan Aulbur, 2004 dan Pratiwi, 2005) 
Structural capital merupakan seluruh non human storehouses of knowledge dalam organisasi, termasuk database, organizational charts, process manuals, strategies routines, system, budaya dan perlindungan hukum atas hak dan kekayaan intelektual perusahaan (Meritum, 2002; Pablos, 2002). Structural capital merupakan pengetahuan yang tetap berada dalam perusahaan yaitu Memberi kemampuan perusahaan dalam memenuhi proses rutinitas perusahaan dan strukturnya yang mendukung usaha karyawan untuk menghasilkan kinerja intelektual yang optimal serta kinerja bisnis secara keseluruhan (Starovic and Marr, 2004).

Customer capital didefinisikan sebagai hubungan perusahaan dengan stakeholders yang meliputi hubungan antara perusahaan dengan pelanggan, supplier, asosiasi industri, stakeholders dan strategic alliance partner (Kannan dan Aulbur, 2004). Customer capital mencakup image perusahaan, loyalitas pelanggan, kepuasan pelanggan, interaksi dengan pemasok, suppliers channels, licensing agreements dan franchising agreements (Starvoic dan Marr, 2003). Customer capital merupakan pengetahuan yang dikumpulkan oleh perusahaan sebagai hasil pertukaran dengan pihak ke tiga dan potensi akumulasi pengetahuan dimasa depan (Pablos, 2004)

\section{Nilai Perusahaan}

Peningkatan nilai perusahaan dapat tercapai apabila ada kerja sama antara manajemen perusahaan dengan pihak lain, yang meliputi sharehoder dalam membuat keputusan-keputusan keuangan dengan tujuan memaksimumkan modal kerja yang dimiliki. Dalam kenyataannya penyatuan kepentingan kedua pihak tersebut sering kali menimbulkan masalah. Adanya masalah diantara manajer dan pemegang saham disebut masalah agensi (agency problem). Dalam konsep theory of the firm adanya agency problem akan menyebabkan tidak tercapainya tujuan keuangan perusahaan, yaitu meningkatkan nilai perusahaan dengan cara memaksimalkan kekayaan pemegang saham. Untuk itu diperlukan sebuah kontrol dari pihak luar dimana peran monitoring dan pengawasan yang baik akan mengarahkan tujuan sebagaimana mestinya (Jensen \& Meckling, 1976), dalam hal ini peran intellectual capitan perusahaan sangat berpengaruh terhadap siklus hidup perusahaan, karena dengan sumber daya yang dimiliki perusahaan dapat meminimalkan agency problem sehingga dapat meningkatkan kinerja perusahaan. 


\section{Tobin's Q Ratio}

Pengukuran nilai perusahaan dengan menggunakan Tobin's $Q$ tidak hanya memberikan gambaran pada aspek fundamental saja, tetapi juga sejauh mana pasar menilai perusahaan dari berbagai aspek yang dilihat oleh pihak luar termasuk investor. Tobin's $Q$ mewakili sejumlah variabel yang penting dalam pengukuran kinerja, antara lain aktiva tercatat perusahaan, kecenderungan pasar yang memadai seperti pandangan-pandangan analis mengenai prospek perusahaan, dan variabel intellectual capital atau intangible asset.

Secara khusus, Tobin's $Q$ ratio sering digunakan sebagai alat pengukur nilai intangible asset atau modal intelektual suatu perusahaan seperti kekuatan monopoli, sistem manajerial dan peluang pertumbuhan. Karena adanya intellectual capital inilah suatu perusahaan sering dinilai lebih oleh pasar, hal tersebut tercermin dari banyaknya perusahaan yang memiliki aktiva berwujud yang tidak signifikan dalam laporan keuangan namun penghargaan pasar terhadap perusahaan-perusahaan tersebut sangat tinggi (Rupert dalam Juniarti, 2009).

Tobin's $q$ adalah gambaran statistik yang berfungsi sebagai proksi dari nilai perusahaan dari perspektif investor, seperti dalam defisisi yang telah dijelaskan di atas bahwa Tobin's q merupakan nilai pasar dari firm's assets dan replacement value of those assets. Secara matematis Tobin's $q$ dapat dihitung dengan formulasi rumus sebagai berikut:

\section{$Q=(M V S+M V D) / R V A$}

Dimana: MVS = Market value of all outstanding stock; MVD = Market value of all debt; RVA = Replacement value of all production capacity

Perusahaan dengan $q s$ yang tinggi, atau $q s>1,00$ memiliki peluang investasi yang baik (Lang, Stulz \& Walkling, 1989), memiliki potensi pertumbuhan yang tinggi (Tobin \& Brainard,1968; Tobin, 1969) dan menunjukkan bahwa manajemen memiliki performa yang baik dengan aktiva dalam pengelolaannya. Mengingat bahwa dalam simulasi permainan, $q$ memiliki predictive validity sebagai high performing firms indicator, dan benar dalam dunia nyata perusahaan, maka $q$ dapat digunakan sebagai indikator utama untuk mengukur keberhasilan perusahaan. 
Di dalam penggunaannya, Tobin's $q$ mengalami modifikasi. Modifikasi Tobin's $q$ versi Chung dan Pruitt (1994) telah digunakan secara konsisten karena disederhanakan diberbagai simulasi permainan. Modifikasi versi ini secara statistik kira-kira mendekati Tobin's $q$ asli dan menghasilkan perkiraan 99,6\% dari formulasi aslinya yang digunakan oleh Lindenberg \& Ross (198I). Formulasi rumusnya sebagai berikut:

$$
\mathbf{Q}=(\text { MVS + D) } / \text { TA }
$$

Dimana: MVS = Market value of all outstanding shares; $\mathrm{D}=$ Debt; TA = Firm's asset's.

Market value of all outstanding shares (MVS) merupakan nilai pasar saham yang diperoleh dari perkalian jumlah saham yang beredar dengan harga saham (Outstanding Shares*Stock Price). Debt merupakan besarnya nilai pasar hutang, dimana nilai ini dapat dihitung dengan menggunakan persamaan sebagai berikut:

\section{$D=(A V C L-A V C A)+A V L T D$}

Dimana: AVCL = Accounting value of the firm's Current Liabilities (Short Term Debt + Taxes Payable); AVLTD = Accounting value of the firm's Long Term Debt (Long Term Debt); $\mathrm{AVCA}=$ Accounting value of the firm's Current Assets. (Cash + Account Receivable + Inventories).

\section{Hipotesis}

$\mathrm{HI}=$ Intellectual capital disclosure berpengaruh positif terhadap nilai perusahaan.

$\mathrm{HIa}=$ Human Capital disclosure berpengaruh positif terhadap nilai perusahaan.

$\mathrm{HIb}=$ Structural Capital disclosure berpengaruh positif terhadap nilai perusahaan.

$\mathrm{HIc}=$ Customer Capital disclosure berpengaruh positif terhadap nilai perusahaan.

$\mathrm{H} 2$ = Perusahaan yang berada pada tahap growth akan memiliki hubungan antara intellectual capital disclosure dan nilai pasar yang lebih kuat dibanding pada tahap mature

$\mathrm{H} 2 \mathrm{a}=$ Perusahaan yang berada pada tahap growth akan memiliki hubungan antara human capital disclosure dan nilai pasar yang lebih kuat dibanding pada tahap mature

$\mathrm{H} 2 \mathrm{~b}=$ Perusahaan yang berada pada tahap growth akan memiliki hubungan antara structural capital disclosure dan nilai pasar yang lebih kuat dibanding pada tahap mature

$\mathrm{H} 2 \mathrm{c}=$ Perusahaan yang berada pada tahap growth akan memiliki hubungan antara customer capital disclosure dan nilai pasar yang lebih kuat dibanding pada tahap mature 


\section{METODE}

\section{Jenis Penelitian}

Jenis penelitian yang dilakukan adalah penelitian kausal digunakan untuk menjawab permasalahan yang dibutuhkan sebagai untuk dianalisis kuantitatif, pada penelitian ini serangkaian pengukuran hasilnya dapat dinyatakan dalam bentuk angka. Berdasarkan cara memperolehnya jenis data yang dipakai didalam penelitian ini adalah data sekunder. Adapun data yang dibutuhkan adalah data laporan keuangan tahunan dan annual report perusahaan manufaktur go public selama periode 2009 2011 .

\section{Populasi dan Sampel Penelitian}

Penelitian ini menggunakan data sekunder, populasi pada penelitian ini adalah perusahaan manufaktur yang tercatat di Bursa Efek Indonesia pada tahun 2009-20 II. Penulis juga melakukan akses terhadap situs web yaitu www.idx.co.id untuk memperoleh data yang diperlukan. Sampel diambil dengan menggunakan metode purposive sampling, yaitu pengambilan sampel yang dilakukan sesuai dengan tujuan penelitian yang telah ditetapkan, kriteria-kriteria yang digunakan dalam pengambilan sampel adalah : (I) Perusahaan menerbitkan laporan keuangan tahunan dan annual report perusahaan yang bisa diakses melalui Internet. (2) Memiliki kelengkapan data laporan keuangan tahunan dan annual report pada 2009 sampai dengan 201I. (3) Secara konsisten tercatat di Bursa Efek Jakarta hingga akhir 20II. (4) Perusahaan tidak melakukan merger, akuisisi, divestasi atau bentuk restrukturisasi lainnya

\section{Metode Analisis}

Pada penelitian ini, untuk mengolah dan membahas penelitian yang telah diperoleh dan untuk menguji hipotesis yang digunakan teknik analisa regresi berganda, hal tersebut dapat disimpulkan secara langsung mengenai pengaruh masing-masing variabel bebas yang digunakan secara parsial atau secara bersamasama. Model regresi yang digunakan adalah :

$$
\begin{array}{ll}
\mathrm{TQ}= & \alpha+\beta_{1} \mathrm{ICD}+\beta_{2} \mathrm{LCS}+\beta_{3} \mathrm{ICD} \times \mathrm{LCS}+\beta_{4} \mathrm{SIZE}+\beta_{5} \mathrm{LEV}+\mathrm{e} \\
\mathrm{TQ}= & \alpha+\beta_{1} \mathrm{HCD}+\beta_{2} \mathrm{SCD}+\beta_{3} \mathrm{RCD}+\beta_{4} \mathrm{LCS}+\beta_{5} \mathrm{LCS} \times \mathrm{HCD}+\beta_{6} \mathrm{LCS} \times \\
& \mathrm{SCD}+\beta_{7} \mathrm{LCS} \times \mathrm{RCD}+\beta_{8} \mathrm{SIZE}+\beta_{9} \mathrm{LEV}+\mathrm{e}
\end{array}
$$

Dimana :

TQ = Tobin's $\mathrm{Q}$ untuk menghitung nilai perusahaan dihitung berdasarkan penelitian Klapper dan Love dalam Darmawati dan Khomsiyah (2003) 


yang telah menyesuaikan rumus Tobin's $Q$ dengan kondisi transaksi
keuangan perusahaan - perusahaan di Indonesia.
Indeks pengungkapan human capital disclosure, diukur dengan metode
content analysis mengikuti Li et al., (2008)

HASIL DAN PEMBAHASAN

\section{Statistik Deskriptif}

Berdasarkan 70 sampel perusahaan manufaktur periode 2009-20II terdapat 210 sampel dapat dijelaskan secara keseluruhan dalam penelitian ini, dilihat bahwa variabel intellectual capital disclosure menunjukan nilai mínimum 0.70000 , dan nilai maximum adalah sebesar 0.90000 . Hal tersebut menunjukkan bahwa perusahaan manufaktur pada penelitian ini sudah mengungkapkan intellectual capital disclosure dalam annual report perusahaan. Jika dilihat dari masing-masing ketegori intellectual capital disclosure, nilai terbesar adalah variabel human capital disclosure dan structure capital disclosure dengan nilai rata - rata 0.835238 I dan 0.8276190 , dan nilai terkecil adalah variabel customer capital disclosure dengan nilai rata-rata sebesar $0.765238 \mathrm{I}$. Hal ini menujukkan bahwa pengungkapan human capital disclosure dan structure capital disclosure lebih tinggi dibandingkan dengan pengungkapan customer capital disclosure, Sehingga pengungkapan komponen intellectual capital discosure pada penelitian ini sangat menarik untuk diteliti lebih lanjut, apakah human capital disclosure dan struktur capital disclosure memberikan pengaruh lebih besar terhadap nilai perusahaan dibandingkan customer capital disclosure.

Dilihat dari besarnya nilai perusahaan menunjukkan nilai rata-rata sebesar 2.6961905 hal tersebut dapat dijelaskan bahwa annual report perusahaan yang di pulikasi di BEl memberikan kontribusi positif terhadap saham perusahaan, sehingga berdampak pada kinerja perusahaan dari tahun ke tahun mengalami peningkatan 
menjadi lebih baik. jika dilihat dari life cycle stage menunjukkan nilai rata-rata I.7I hal tersebut dapat dijelaskan bahwa rata-rata perusahaan dalam penelitian ini tergolong pada tahap growth, hal tersebut menunjukkan bahwa pertumbuhan perusahaan dari tahun ketahun mengalami peningkatan, selain itu terdapat tren positif dengan adanya peningkatan penjualan serta perkembangan usaha yang dialami perusahaan sehingga kinerja perusahaan menjadi baik. Size dan leverage menunjukan nilai rata-rata sebesar 12.017I429 dan 0.5557|43. Hal tersebut dapat dijelaskan bahwa, perusahaan manufaktur yang dijadikan sampel penelitian tergolong perusahaan besar, dengan demikian perusahaan manufaktur pada penelitian ini bagus untuk dijadikan sampel penelitian.

\section{Hasil Pengujian Hipotesis}

\section{Intellectual Capital Disclosure terhadap Nilai Perusahaan}

Tabel I Hasil Pengujian Intellectual Capital Disclosure terhadap Nilai Perusahaan

\begin{tabular}{|l|r|r|r|l|}
\hline \multicolumn{1}{|c|}{ Variabel } & Koefisien & t - value & \multicolumn{1}{c|}{ Sig } & Kesimpulan \\
\hline Konstanta & -4.770 & -3.316 & .001 & Diterima \\
ICD & 2.351 & 1.646 & .102 & Ditolak \\
\hline Variabel Kontrol & & & & \\
\hline Size & .290 & 3.952 & .000 & Diterima \\
Leverage & .659 & 5.702 & .000 & Diterima \\
\hline R & .450 & & \\
R Square & .203 & & \\
Adj. R Square & .190 & & \\
Dubin-Watson & 1.875 & & \\
ANOVA F & 15.441 & Sig & .000 \\
\hline
\end{tabular}

Signifikan $=0.05$ atau $5 \%$

Dependent Variable : Tobin's Q Ratio

Hasil pengujian dari variabel independen dimasukkan kedalam model regresi, dihasilkan variabel intellectual capital disclosure menunjukkan tidak berpengaruh signifikan terhadap nilai perusahaan sebesar 0.102 lebih besar dari 0.05 , sedangkan variabel kontrol yaitu size dan leverage dalam penelitian ini menunjukkan hasil berpengaruh signifikan sebesar 0.000 pada masing - masing variabel, hasil ini menunjukkan size dan leverage sebagai variabel kontrol 
mempunyai kontribusi positif terhadap nilai perusahaan. Dari hasil tersebut dapat disimpulkan dengan persamaan matematis :

Nilai perusahaan $=-4.770+2.35 I * I C D+0.290 *$ Size $+0.659 *$ Lev

\section{Komponen Intellectual Capital Disclosure terhadap Nilai Perusahaan}

Tabel 2 Hasil Pengujian Komponen Intellectual Capital Disclosure terhadap Nilai Perusahaan

\begin{tabular}{|l|r|r|r|l|}
\hline \multicolumn{1}{|c|}{ Variabel } & Koefisien & t - value & \multicolumn{1}{l|}{ Sig } & Kesimpulan \\
\hline Konstanta & -5.798 & -4.468 & .000 & Diterima \\
HCD & .922 & .955 & .341 & Ditolak \\
SCD & -.303 & -.322 & .748 & Ditolak \\
CCD & 3.662 & 4.032 & .000 & Diterima \\
\hline Variabel Kontrol & & & & \\
\hline Size & .254 & 3.558 & .000 & Diterima \\
Leverage & .686 & 6.178 & .000 & Diterima \\
\hline R & .524 & & & \\
R Square & .275 & & & \\
Adj. R Square & .255 & & & \\
Dubin-Watson & 1.872 & & & \\
ANOVA F & \multicolumn{5}{|c|}{ Sig } & .000 & \\
\hline
\end{tabular}

\section{Signifikan $=0.05$ atau $5 \%$}

Dependent Variable : Tobin's Q Ratio

Hasil pengujian dari ketiga komponen intellectual capital disclosure yaitu human capital disclosure, struktur capital disclosure dan customer capital disclosure dapat dilihat pada nilai R Square untuk masing - masing persamaan sebesar 0.275, hal tersebut berarti $27,5 \%$ dapat dijelaskan dalam dari ketiga komponen intellectual capital disclosure, sedangkan sisanya sebesar 72,5\% dijelaskan oleh variabel lain yang tidak dapat diteliti dalam penelitian ini. Uji $F$ menunjukkan bahwa $F$ hitung sebesar 13.653 dengan probabilitas 0.000 lebih kecil dari 0.05 , hal tersebut membuktikan bahwa model regresi dapat yang diguakan untuk memprediksi nilai perusahaan, atau dapat dikatakan bahwa komponen intellectual capital disclosure berpengaruh terhadap nilai perusahaan.

Hasil pengujian dari variabel independen dimasukkan kedalam model regresi dihasilkan variabel human capital disclosure dan structure capital disclosure tidak menunjukkan pengaruh signifikan terhadap nilai perusahaan yaitu sebesar 
$0.34 \mathrm{I}$ dan 0.748 , sedangkan custome capital disclosure menunjukkan hasil signifikan terhadap nilai perusahaan sebesar 0.000 lebih besar dari 0.05 . Variabel kontrol yaitu size dan leverage dalam penelitian ini menunjukkan hasil signifikan sebesar 0.000 pada masing - masing variabel, hasil ini menunjukkan size dan leverage sebagai variabel kontrol secara konsisten mempunyai pengaruh terhadap nilai perusahaan. Dari hasil tersebut dapat disimpulkan dengan persamaan matematis :

Nilai perusahaan $=-5.798+0.922 * \mathrm{HCD}-0.303 * \mathrm{SCD}+3.662 * \mathrm{CCD}+$ $0.254 *$ Size $+0.686 *$ Lev

\section{Life Cycle Stage dalam memoderasi Intellectual Capital Disclosure dan Nilai Perusahaan}

Tabel 3 Hasil Pengujian Life Cycle Stage dalam memoderasi Intellectual Capital Disclosure dan Nilai Perusahaan

\begin{tabular}{|l|r|r|r|l|}
\hline \multicolumn{1}{|c|}{ Variabel } & Koefisien & \multicolumn{1}{c|}{$\mathbf{t}$ - value } & \multicolumn{1}{c|}{ Sig } & Kesimpulan \\
\hline Konstanta & -3.039 & -3.411 & .001 & Diterima \\
LCS.ICD & .253 & 1.712 & .089 & Ditolak \\
\hline Variabel Kontrol & & & & \\
\hline Size & .275 & 3.711 & .000 & Diterima \\
Leverage & .623 & 5.439 & .000 & Diterima \\
\hline R & .451 & & & \\
R Square & .204 & & & \\
Adj. R Square & .191 & & & \\
Dubin-Watson & 1.891 & & \\
ANOVA F & 15.533 & Sig & .000 \\
\hline
\end{tabular}

Signifikan $=0.05$ atau $5 \%$

Dependent Variable : Tobin's Q Ratio

Hasil pengujian dapat dilihat pada nilai R Square untuk masing masing persamaan sebesar 0.204 , hal tersebut berarti $20.4 \%$ dapat dijelaskan dalam pengungkapan life cycle stage dalam memoderasi hubungan intellectual capital disclosure dan nilai perusahaan, sedangkan sisanya sebesar $79.6 \%$ dijelaskan oleh variabel lain yang tidak dapat diteliti dalam penelitian ini. Uji $F$ dihasikan bahwa $F$ hitung sebesar 15.533 dengan probabilitas 0.000 lebih kecil dari 0.05 , hal tersebut membuktikan bahwa model regresi dapat diguakan untuk memprediksi 
nilai perusahaan atau dapat dikatakan bahwa life cycle stage berpengaruh dalam moderasi hubungan intellectual capital disclosure dan nilai perusahaan.

Hasil pengujian dari variabel independen yang dimasukkan kedalam model regresi, variabel life cycle stage dalam memoderasi hubungan intellectual capital disclosure dan nilai perusahaan menunjukkan tidak berpengaruh signifikan sebesar 0.089 diatas 0.05 , Sehingga secara konsisten life cycle stage dalam memoderasi hubungan intellectual capital disclosure dan nilai tidak berpengaruh signifikan. Variabel kontrol yaitu size dan leverage dalam penelitian ini menunjukkan hasil berpengaruh signifikan sebesar 0.000 pada masing - masing variabel, hasil ini menunjukkan size dan leverage sebagai variabel kontrol mempunyai kontribusi positif terhadap nilai perusahaan. Dari hasil tersebut dapat disimpulkan dengan persamaan matematis :

Nilai perusahaan $=-3.039+0.253 *$ LCS.ICD $+0.275 *$ Size $+0.623 *$ Lev

\section{Life Cycle Stage dalam memoderasi komponen Intellectual Capital}

\section{Disclosure dan Nilai Perusahaan}

Tabel 4 Hasil Pengujian Peran Life Cycle Stage dalam memoderasi komponen Intellectual Capital Disclosure dan Nilai Perusahaan

\begin{tabular}{|l|r|r|r|l|}
\hline \multicolumn{1}{|c|}{ Variabel } & Koefisien & t - value & \multicolumn{1}{c|}{ Sig } & Kesimpulan \\
\hline Konstanta & -2.698 & -3.083 & .002 & Diterima \\
LCS.HCD & -.196 & -.409 & .683 & Ditolak \\
LCS.SCD & -1.089 & -2.274 & .024 & Diterima \\
LCS.CCD & 1.710 & 3.403 & .001 & Diterima \\
\hline Variabel Kontrol & & & & \\
\hline Size & .240 & 3.294 & .001 & Diterima \\
Leverage & .622 & 5.589 & .000 & Diterima \\
\hline R & .508 & & \\
R Square & .258 & & & \\
Adj. R Square & .237 & & & \\
Dubin-Watson & 1.864 & & & \\
ANOVA F & 12.500 & Sig & \\
\hline
\end{tabular}

Signifikan $=0.05$ atau $5 \%$

Dependent Variable : Tobin's Q Ratio

Hasil pengujian dari ketiga komponen intellectual capital disclosure dapat dilihat pada nilai $\mathrm{R}$ Square untuk masing - masing persamaan sebesar 0.258 , hal 
tersebut berarti $25.8 \%$ dapat dijelaskan dalam pengungkapan life cycle stage dalam memoderasi hubungan komponen intellectual capital disclosure dan nilai perusahaan, sedangkan sisanya sebesar $79.6 \%$ dijelaskan oleh variabel lain yang tidak dapat diteliti dalam penelitian ini. Uji $F$ dihasikan bahwa $F$ hitung sebesar 12.500 dengan probabilitas 0.000 lebih kecil dari 0.05 , hal tersebut membuktikan bahwa model regresi dapat diguakan untuk memprediksi nilai perusahaan atau dapat dikatakan bahwa peran life cycle stage berpengaruh dalam moderasi hubungan intellectual capital disclosure dan nilai perusahaan.

Hasil pengujian variabel independen yang dimasukkan kedalam model regresi, variabel life cycle stage dalam memoderasi hubungan komponen intellectual capital disclosure dan nilai perusahaan, menunjukkan life cycle stage dalam memoderasi human capital disclosure dan nilai perusahaan tidak berpengaruh signifikan sebesar 0.683 diatas 0.05 . Sedangkan life cycle stage berpengaruh signifikan dalam memoderasi hubungan kedua structur capital disclosure dan nilai perusahaan serta customer capital disclosure dan nilai perusahaan, yaitu sebesar 0.024 dan 0.00 I. Dari hasil tersebut dapat disimpulkan dengan persamaan matematis :

Nilai perusahaan $=-2.698-0.196 *$ LCS.HCD $-1.089 *$ LCS.SCD + 1.710*LCS.CCD + 0.240*Size + 0.622*Lev

\section{Pembahasan Hasil Penelitian}

\section{Intellectual Capital Disclosure terhadap Nilai Perusahaan}

Berbagai macam penelitian intellectual capital disclosure dari penelitian terdahulu masih tidak konsisten, karena terdapat perbedaan hasil pengujian atas beberapa variabel yang diprediksi untuk mengungkapkan intellectual capital disclosure dalam annual report laporan keuangan. Menurut Bruggen et al., (2009) dan Whiting dan Miller (2008). Dari hasil ini dapat disimpulkan bahwa intellectual capital disclosure dalam annual report perusahaan tidak berpengaruh terhadap nilai perusahaan. Kemungkinannya adalah kurangnya transparansi yang dirasakan oleh pemakai laporan keuangan terutama investor, yang disebabkan adanya asymmetric information dalam laporan keuangan tahunan. Menurut Utami (2010) pengaruh pengungkapan intellectual capital disclosure terhadap asymmetric 
information negatif dan signifikan, sehingga semakin tinggi tingkat pengungkapan maka akan memperkecil asymmetric information. Namun sebaliknya, besarnya size dan leverage perusahaan berpengaruh positif terhadap nilai perusahaan, sehingga semakin besar ukuran perusahaan maka akan berpengaruh terhadap nilai perusahaan. Bozzolan (2003), Garcia-Meca (2005), dan Oliveira (2008). sehingga dapat disimpulkan bahwa belum ada standar pengungkapan intellectual capital discosure berdampak pada sinyal (signal) informasi yang disampaikan kepada investor belum berkontribusi dalam meningkatkan kinerja perusahaan, sehingga para investor lebih melihat dari ukuran perusahaan. Semakin tinggi tingkat pengungkapan size dan leverage maka akan berkontribusi positif dalam memberikan sinyal (signal) mengenai informasi yang dimiliki perusahaan kepada investor dan dapat dipastikan bahwa sinyal (signal) tersebut merupakan informasi yang dapat dipercaya.

\section{Komponen Intellectual Capital Disclosure terhadap Nilai \\ Perusahaan}

Kemungkinan human capital disclosure terhadap nilai perusahaan tidak berpengaruh adalah dalam melakukan investasi para investor lebih banyak melihat sisi fundamental perusahaan bandingkan dengan sumber daya yang dimiliki perusahaan. Resource Based View Theory pada pengungkapan human capital disclosure dengan sumber daya yang unik dan tidak dapat ditiru tidak memiliki kontribusi kontribusi bagi perusahaan. Kemungkinan structure capital disclosure tidak berpengaruh terhadap nilai perusahaan adalah, masih ada filosofi manajemen yang berpengaruh pada budaya kerja perusahaan dan hubungan afiliasi atau kelompok dalam struktur perusahaan dari pemegang saham. Disamping itu, dalam penelitian ini tidak membedakan karyawan asing atau non asing dalam struktur organisasi perusahaan yang dapat berkontribusi pada kinerja perusahaan.

Sedangkan kemungkinan customer capital disclosure berpengaruh positif dan signifikan terhadap nilai perusahaan, disebabkan adanya kemampuan perusahaan menciptakan suatu hubungan atau relasi yang harmonis dengan para mitra perusahaan, guna meningkatkan image perusahaan dan loyalitas pelanggan 
serta intertaksi dengan pemasok melalui lecensing agreements dan franchising ageements juga terbukti efektif meningkatkan kinierja yang lebih baik (Starvoic dan Marr, 2003) dan (Pablos, 2004).

\section{Life Cycle Stage dalam memoderasi Intellectual Capital Disclosure dan Nilai Perusahaan}

Hasil penelitian ini menunjukkan bahwa life cycle stage dalam memoderasi hubungan intellectual capital disclosure dan nilai perusahaan menunjukkan hasil tidak berpengaruh. Kemungkinan penyebab adalah para investor hanya melihat dari sisi pertumbuhan perusahaan dan tidak melihat pengungkapan intellectual capital disclosure dalam annual report laporan tahunan. serta belum adanya stándar pengungkapan intellectual capital disclosure dalam anual report perusahaan. Utami (2010). Sehingga sinyal (signal) yang dihasilkan dari pengungkapkan intellectual capital disclosure tidak berkontribusi bagi para investor. Kemungkinan penyebab lain adalah perusahaan cenderung menginvestasikan kembali laba guna meningkatkan peryumbuhan perusahaan. Hal tersebut juga sejalan dalam penelitian Gul (1999) dalam Lestari (2004), AINajjar dan Belkoui (200I) bahwa pada tahap growth dan mature berpengaruh negatif terhadap kesempatan berinvestasi.

\section{Life Cycle Stage dalam memoderasi komponen Intellectual Capital Disclosure dan Nilai Perusahaan}

Kemungkinan life cycle stage dalam memoderasi hubungan human capital disclosure dan nilai perusahaan tidak berpengaruh berpengaruh adalah, keterkaitan undang-undang ketenagakerjaan mengenai sistem kerja outsorcing bagi karyawan yang berakibat menurunnya komitmen karyawan dalam bekerja.

life cycle stage dalam moderasi hubungan structure capital disclosure dan nilai perusahan, serta customer capital disclosure dan nilai perusahaan berpengaruh positif signifikan, kemungkinan tersebut disebabkan karena pada tahap growth perusahaan menciptakan struktur organisasi dan budaya kerja yang baik, knowledge dalam organisasi termasuk invovasi dan teknologi, serta budaya kerja dan perlindungan hukum atas hak dan kekayaan intelektual yang dimiliki perusahaan sehingga dapat mendukung produktivitas karyawan, disamping 
berdampak juga terhadap hubungan kepada para plenggan dengan memberikan apresiasi yang tingga sehingga hubungan baik tercipta untuk meningkatkan kinerja perusahaan (Meritum, 2002; Pablos, 2002). Hal tersebut sejalan dengan signalling theory yaitu dengan memberikan sinyal (signal) mengenai informasi structur capital disclosure dan customer capital disclosure yang lebih tinggi maka informasi yang dimiliki perusahaan dapat dipercaya, sehingga ekspektasi dalam pengungkapan berperan dapat mempengaruhi kinerja perusahaan kepada pasar dan mengurangi asymmetry information (Oliviera et al., 2008)

\section{SIMPULAN}

Pengungkapan intellectual capital disclosure pada annual report menunjukkan tidak berpengaruh terhadap nilai perusahaan. Dari ketiga kategori intellectual capital disclosure, pengungkapan human capital disclosure dan structure capital disclosure tidak berpengaruh terhadap perusahaan. Akan tetapi pengungkapan customer capital disclosure berpengaruh terhadap nilai perusahaan. Hal ini membuktikan pentingnya pengungkapan customer capital disclosure dalam strategi bersaing usaha sehingga berkontribusi untuk meningkatkan nilai perusahaan. Peran life cycle stage dalam memoderasi hubungan intellectual capital disclosure dan nilai perusahaan tidak berpengaruh. Dari kategori pengungkapan intellectual capital disclosure, peran life cycle stage dalam memoderasi hubungan human capital disclosure dan nilai perusahaan tidak berpengaruh terhadap nilai perusahaan. Akan tetapi, peran life cycle stage dalam memoderasi hubungan structure capital disclosure dan nilai perusahaan serta customer capital diclosure dan nilai perusahaan berpengaruh signifikan.

\section{PUSTAKA ACUAN}

AINajjar, F.K. dan A.R. Belkauoi. (200I). Empirical validation of a general model of growth opportunities. Managerial Finance, 27 (3): 72-88

Aggarwal, R., T. Hiraki, and R. P. Rao. (1992). "Price/Book Value Ratios and Equity Return on the Tokyo Stock Exhange: Empirical Evidence of an Anomalous Regularity”. The Financial Review. Vol. 27. No. 4: 589 - 605. 
Belkaoui, A. R. (2003). "Intellectual Capital and Firm Performance of US Multinational Firms: a Study of The Resource-Based and Stakeholder Views”. Journal of Intellectual Capital. Vol. 4. No. 2: 215 - 226.

Bontis, N. (1998) Intellectual Capital : An Exploratory Study That Develops Measures and Models. Management Decision, 36 (2), 63-76

Bontis,N., Crossan, M and Hulland, J. (200I). Managing an Organizational Learning System by Aligning Stocks and Flows, Journal of Management Studies 39 (4) : 437-469.

Bontis, N.(2002). Managing Organizational Knowledge by Diagnosing Intellectual Capital : Framing and Advancing The State of The Field. In Bontis, N. (Ed.) World Congress on Intellectual Capital Reading, ButterworthHeinemann.KMCl Press, Boston, MA, 13-56

Bukh, P. N. (2003). "Commentary: The Relevance of Intellectual Capital Disclosure: A Paradox?" Accounting, Auditing \& Accountability Journal, 16 (I), 49-56.

Bollen, L., P. Vergauwen, and S. Schnieders. (2005). “Linking Intellectual Capital and Intellectual Property to Company Performance”. Management Decision. Vol. 43. No. 9: $\mid 161$ - 1185.

Chen et al. 2005. An empirical investigation of the relationship between intellectual capital and firm's market value and financial performance. Journal of Intellectual Capital, Vol. 6, Issue 2.

Firer S., and Williams M. 2003. Intellectual capital and traditional measures of corporate performance “. Journal of Intellectual Capital Vol. 4 No. 3.

Ghozali, I. (2006). Analisis Multivariate dengan Program SPSS. Semarang: Badan Penerbit Universitas Diponegoro.

Guthrie, J and R. M. Petty (2000). "Intellectual Capital: Australian Annual Reporting Practices”. Journal of Intellectual Capital. Vol. I. No. 3: 24I -25I.

Gul, F.A. (1999). Government share ownership, investment opportunity set and corporate policy choices in China. Pacific-Basin Finance Journal, 7:I57-I72

Gup, B.A, dan P. Agrrawal. (1996). The Product Life Cycle : A Paradigm for Understanding Financial Management. Financial Practice and Education, FII/Winter : $41-48$ 
Gumanti, T.A dan Puspitasari, N.(2008). Siklus hidup perusahaan dan kaitannya dengan investment opportunity set, risiko dan kinerja financial. Jurnal Akuntansi \& Bisnis, Vol 8(2) 139-150

Guthrie,R.Petty , F.Ferrier, and R.Well. (1999. There is no Accounting for Intellectual Capital in Australia: Review of Annual Reporting Practices and the Internal Measurement of Intangible Within Australian Organizations. Paper presented at The International Symposium Measuring and Reporting Intellectual Capital, Experiences, Issues and Prospect,OECD, June, Amsterdam.

Garcia-Meca, E. dan Martinez, I. (2005). “Assesing the Quality of Disclosure on Intangible in the Spanish Capital Market”. European Business Review, 17 (4), 63-94.

Hair, et al. (1998). Multivariate Data Analysis, Fifth Edition, Prentice-Hall International, Inc.

Istianingsih. (20II). Faktor-Faktor Penentu Pengungkapan Informasi dan Kinerja Modal Intelektual serta Dampaknya terhadap Kemampuan Imbal Hasil Saham dalam Memprediksi Laba Masa Depan Perusahaan. Disertasi, Universitas Indonesia, Jakarta $201 \mathrm{I}$.

Kin Gan and Zakiah Saleh. (2008). Intellectual Capital and Corporate Performance of Technology-Intensive Companies: Malaysia Evidence. Asian Journal Of Business and Accounting I (I) : I I3-130.

Lestari, H. (2004). Pengakuan kebijakan utang, kebijakan deviden, risiko dan profitabilitas perusahaan terhadap set kesempatan investasi. Simposium Nasional Akuntansi, 7: 1059-1069

Oliveira, Lídia, Lúcia Lima Rodrigues, dan Russell Craig (2008). Applying Voluntary Disclosure Theories to Intangibles Reporting: Evidence from the Portuguese Stock Market.

Pratiwi Dwi Astuti. (2005). Hubungan Intellectual Capital dan Business Performance. Jurnal Maksi 5 (januari) : 34-57.

Pagalung, G. (2002). Pengaruh kombinasi keunggulan dan keterbatasan perusahaan terhadap set kemampuan investasi (IOS). Simposium Nasional Akuntansi, Semarang, 5 : 662-673 
Reed,K. (2000). The Dynamics of Intellectual Capital. Ph.D Dissertation. University of Connecticut, United States of America.

Starovic,D., and Marr, B. (2004). Understanding Corporate Value : Managing and Reporting Intellectual Capital . Chartered Institute of Management Accountants.

Stewart, T. A. (1997). “Intellectual Capital: The New Wealth of Organization”. Avalable at: www.intellectualcapital.com. (accessed June 2009).

Sawarjuwono, T. dan A. P. Kadir. (2003). “Intellectual Capital: Perlakuan, Pengukuran, dan Pelaporan (Sebuah Library Research)”. Jurnal Akuntansi dan Keuangan. Vol. 5. No. I: 35 - 57.

Tan et al. 2007. Intellectual capital and financial returns of companies. Journal of Intellectual Capital Vol. 8 No. I, 2007 pp. 76-95

Utami, W. (20I0). Dampak Pengungkapan Sukarela dan Manajemen LabaTerhadap Biaya Modal ekuitas dengan Asimetri Informasi sebagai variabel Intervening. Jurnal Telaah Akuntansi dan Bisnis, Vol I (2), 57-80.

Utami, W. (2009). Pedomam Penyusunan Tesis dan Prosedur Akademik. Jakarta:Mercu Buana.

Utami, W. (2000). Akuntansi Keperilakuan Dan Perannya Dalam Meningkatkan Kegunaan Informasi Akuntansi. Forum's, Vol 05, 2-II.

Bursa Efek Indonesia : http://www.idx.co.id

Dunia Investasi : http://www.duniainvestasi.com/bei/ 